\title{
MODELS OF INTERACTION BETWEEN THE ESTABLISHED AND THE NEW KNOWLEDGE IN POPULAR SCIENCE TEXTS
}

\author{
Viktoryia Yakubava \\ M. A. (Philology), Senior Lecturer at the Department of Theoretical and Applied Linguistics, \\ Mogilev State A. Kuleshov University (Mogilev, Belarus) \\ e-mail: victoria.yakubova83@gmail.com \\ ORCID: 0000-0003-1113-2335
}

The article is based on the concept of knowledge as a unit of linguistic analysis of the popular science text and is focused on scientific knowledge which results from purposeful cognitive activity and encompasses various concepts about reality. In the popular science text, knowledge can either be borrowed from previous texts in the form of concepts, facts, results of previous studies, which we consider established knowledge, or be verbalized as results of new studies or new concepts.

The purpose of the research is to reveal and describe the main patterns of interaction between the old and the new knowledge within the framework of the popular science media text. The scientific knowledge in this text type functions as a dialectal unity of the established and the new knowledge which are interrelated within the semantic structure of the text type under study.

The research has been carried out on the material of 100 articles of British and American newspapers (The Washington Post, The New York Times, The Independent, The Sunday Times, USA Today).

The methodology of the research is based on the previous studies of the popular science text as a unity of semantic components which make up its conventional structure typical of this text type (superstructure) and establish a virtual dialogue between the author and the reader. Contextual analysis and statistical methods are used in determining the fragments of the text which contain the established and the new knowledge.

The research shows that the new scientific knowledge appears in a popular science text through the dynamics of the interchange between the established and the new knowledge. In most English articles, the development of the new knowledge begins with the direct report of research results or with stories about patients, participants of scientific research.

It can also be stated that the interaction of the established and the new scientific knowledge occurs in the form of three patterns: a statement about the results of earlier studies followed by a report on the results of recent studies (or the reverse sequence); a statement about the volume of available information on the scientific problem, followed by a piece of information about a new scientific discovery and its practical significance (or the reverse sequence); and, finally, a statement about established ideas and concepts followed by information about elaboration or updating of the established knowledge, and the addition of new pieces of knowledge. All three models imply the opposition between the established and the new, which illustrates the continuity of the scientific knowledge.

Keywords: popular science text; established knowledge; new knowledge; linguistic markers; semantic structure.

Якубова Вікторія. Моделі взаємодї між відомими та новими знаннями в науково-популярних текстах.

Стаття базується на концепиії знання як одиниці лінгвістичного аналізу науково-популярного тексту та орієнтована на наукові знання, щзо є результатом цілеспрямованої пізнавальної діяльності та охоплюють різні поняття про реальність. $\longrightarrow$ У науково-популярному тексті знання можуть бути запозичені 3 ๑ Yakubava V., 2019 попередніх текстів у формі понять, фактів, результатів 
попередніх досліджень, які вважаємо відомими знаннями, або вербалізовані у формі результатів нових досліджень чи нових понять.

Мета дослідження - розкрити та описати основні закономірності взаємодї відомих і нових знань у науково-популярному медіатексті. Наукове пізнання иього типу тексту функиіонує як діалектична єдність відомого та нового, що взаємопов'язані в межах семантичної структури досліджуваного тексту.

Дослідження виконано на матеріалі 100 статей британських та американських zaзem (The Washington Post, The New York Times, The Independent, The Sunday Times, USA Today).

Методологія дослідження базується на попередніх дослідженнях науковопопулярного тексту як єдності смислових компонентів, що складають його конвенціональну структуру (суперструктуру), прототипову для иьього типу текстів, та встановлюють віртуальний діалог між автором $i$ читачем. Для визначення фрагментів тексту, щя містять відомі та нові знання, використано статистичний метод і метод контекстуального аналізу.

Дослідження засвідчує, що нове наукове знання відображено в науковопопулярному тексті у формі взаємодї між відомим і новим знанням. У більшості англійських статей нові знання формулюються через повідомлення про результати досліджень або розповідей про пацієнтів, учасників наукових досліджень.

Можна також констатувати, що взаємодія відомих $і$ нових наукових знань відбувається за трьома закономірностями: повідомлення про результати попередніх досліджень, після чого йде інформація про результати останніх досліджень (або у зворотній послідовності); повідомлення про наявну інформацію з наукової проблеми, після чого йде повідомлення про нове наукове відкриття та його практичне значення (або у зворотній послідовності); повідомлення про відомі ідеї та поняття, щчо супроводжується докладною чи актуальною інформацією про відоме, а також наведено нові знання. Усі три моделі передбачають протиставлення відомого та нового, щуо ілюструє наступність наукового знання.

Ключові слова: науково-популярний текст; узвичаєні знання; нові знання; лінгвістичні маркери; смислова структура.

\section{Introduction}

The popular science text is designed to popularize new scientific knowledge among non-expert readers, which is specific of this text type. The concept of knowledge serves as a key concept for the analysis of popular science texts from the point of view of the peculiarities of its formation. In this article, knowledge is considered a semantic unit that is essential for the development of its contents.

In linguistics, knowledge is defined as «having experience and understanding that is correct, both subjectively and objectively, and on the basis of which judgments and conclusions that provide purposeful behavior can be made» [Данилевская 2005, p. 14], as well as the product of processing verbal and nonverbal experience. Scientific knowledge is considered as «subjective knowledge, the purpose of which is to reflect the regularities of the reality with the use of the scientific method» [Данилевская 2009, p. 19] and is characterized by the interpretation of facts in the system of concepts of a certain scientific field.

Knowledge as a unit of analysis of popular science texts means scientific knowledge, which is the result of cognitive activity based on the principles of science. It is also the system of concepts about reality, «the results of cognition, scientific information» [Хомутова 2010, p. 231]. Knowledge is considered by researchers as the result of purposeful cognitive activity, product of scientific knowledge, which is verbalized in the text [Данилевская 2005; Баженова 2001; Котюрова 1989; Чернявская 2010]. Thus, new scientific knowledge in the popular science text can be viewed as the results of new research of the scientific problem 
referred to in this text. In this paper, the established knowledge is viewed as «the previously acquired knowledge manifested in existing texts» [Хомутова 2010, p. 59], i. e. the results of previous studies, publications, factual information, concepts already known to science and used in it [Данилевская 2009].

Scientific knowledge is manifested in the dialectical unity and interaction between the established knowledge that is shared by the speakers, and the new knowledge [Баженова 2001, p. 25; Хомутова 2010, р. 59; Данилевская 2009, p. 23; Hyland 2018, Luzón 2013], which interrelate in the semantic structure of a popular scientific text. The established knowledge ensures the continuity of the cognitive activity, accumulation and progress of knowledge, and serves as a criterion for assessing the acceptability of new knowledge [Хомутова 2010, p. 59]. The established and the new knowledge are textual units, the interaction of which in the process of text development ensures its meaningful, semantic and compositional integrity.

\section{Data analysis and discussion}

The study was carried out on the material of 100 articles of British and American newspapers (The Washington Post, The New York Times, The Independent, The Sunday Times, USA Today) [Yakubava 2015].

The disclosure of the new scientific knowledge in a scientific text does not occur only through the logical-semantic sequence of cognitive stages (a problem situation - a problem - a hypothesis, a hypothesis proof - a conclusion / generalization - the formation of a scientific theory), but also through the dynamics of the interchange between the established and the new knowledge [Данилевская 2005, p. 15]. As our analysis has shown, this scheme is not strictly specified in the popular science text and the stages of the cognitive process are presented in a number of sequences.

According to the study results, in the majority of English articles, the development of the new knowledge begins with the direct report of research results. The way of presenting new knowledge through stories about patients, participants of scientific research is commonly used in texts under study.

The study also took the semantic structure of the texts into consideration. The analysis shows that text fragments containing a piece of new knowledge, in approximately equal proportions, can be mainly found in such semantic subcomponents of the text superstructure as research results, the scientist's commentary, the author's commentary, the formulation of a scientific problem [Yakubava 2013; Yakubava 2015; Якубова 2015; Якубова 2019а; Якубова 2019б].

As for the interaction of the established and the new scientific knowledge, the following features characteristic of the texts under research can be outlined. As a rule, articles contain the opposition of the established and the new, which illustrates the continuity of the scientific knowledge. In the terms of the contents of the text, fragments of the established and the new are presented in the form of three basic models.

The first model of the opposition between the established and the new knowledge is a statement about the results of earlier studies followed by a report on the results of recent studies (or the reverse sequence). For example, in the article about new methods of stimulating the production of vital liver cells (hepatocytes), the author first describes the danger of liver disease and the results of earlier studies on this problem: Liver disease is the fifth biggest killer in Britain and is the only major cause of death that has seen a continual year-on-year increase over the past 40 years - more than twice as many people die of liver disease now compared with 
20 years ago (the established knowledge). < ... > The old information is followed by the results of a new study: The latest research, published in the journal Nature Medicine, has unravelled the network of complex biochemical signals that trigger the regeneration of cells within the liver, the body's main organ for filtering harmful toxins from the bloodstream (the new knowledge).

The second model is a statement about the volume of available information on the scientific problem, followed by a piece of information about a new scientific discovery and its practical significance (or the reverse sequence). For example, according to the article about the development of new drugs to treat a number of chronic illnesses, there is a piece of information on the new research results: Researchers have deciphered the atomic three-dimensional structure of the brain's opioid receptors, the protein molecules that are intimately involved in the control of pain and feelings of wellbeing, as well as being the target of the opioid drugs such as morphine, codeine and heroin (the new knowledge). It is followed by a statement that shows the readers that the problem has not been fully solved by researchers so far: <... > There are four types of opioid receptor which work together in ways that are not completely understood (the established knowledge). In contrast, another piece of new information is provided below: Two of them have been deciphered by two teams of researchers who published their work in the journal Nature. <... > While the kappa opioid receptor appears to elevate a person's mood, the mu receptor can depress mood and produce "dissociative psychedelic experiences», which is how magic mint produces its effect, the scientists said (the new knowledge).

The third model is represented by a statement about ideas and concepts that have long existed in science, followed by information about elaboration or updating of the established knowledge, and the addition of new pieces of knowledge. For instance, the article about the correlation between exercise and mental health begins with a piece of knowledge established by researchers previously in this particular field of study: The widely accepted view that exercise helps dispel depression and anxiety is misleading (the established knowledge), since a common set of genes makes the most mentally healthy also the most prone to exercising, a scientist said over the weekend. The information about previous findings is followed by the results of a recent study on the same problem: The controversial Dutch report on 7,200 twins and 1,200 of their siblings raises questions about large U.S. studies that show exercise improves mood even in those with major depression. The evidence points to common genes influencing both mental health and exercise behavior: <...> the most mentally healthy tend to be active, and genes, not environment, largely determine who they will be (the new knowledge).

To convey the interaction of the established and the new knowledge in the texts under research, certain linguistic means are used. In English articles, the established knowledge is mainly marked with the help of adverbials of time (years ago, last week, etc.), adjectives such as initial, early, previous, etc. In its turn, the new knowledge is marked with the help of linguistic units containing the seme of 'related to the nearest past or present', 'first created': the adverbials of time (now, this week, recently, today), and adjectives (new, first, recent, growing), etc. For instance, in the article about the study of human germs it is pointed out that the study is new and unique: For the first time, scientists have cataloged human germs, determining that more than 10,000 species of microbes can be found in and on a healthy person. In the article about the human microbiome there is a Present Continuous verb form used to emphasize that the studies continue at present and are new: For a century, doctors have waged war against bacteria, using antibiotics as 
their weapons. But that relationship is changing as scientists become more familiar with the 100 trillion microbes that call us home - collectively known as the microbiome.

In addition, the opposition between the established and the new is verbalized through the opposition of the present and the past tense verb forms, which emphasizes the novelty of the results obtained by scientists. In the article about the studies of the phenomenon of happiness, a simple tense form is opposed to the perfect tense form to imply that recent study results are of great current interest: The pursuit of happiness is seen as a fundamental human right and it is often linked with wealth (the established knowledge), yet studies have shown that the richest countries do not always have the happiest people (the new knowledge).

The contrast between fragments of the established and the new knowledge is also expressed by means of conjunctions since, but, yet: The pursuit of happiness is seen as a fundamental human right and it is often linked with wealth (the established knowledge), yet studies have shown that the richest countries do not always have the happiest people (the new knowledge).

\section{Conclusion}

Thus, the popular science text is the carrier of new scientific knowledge, which is the result of the latest scientific research. The new knowledge in popular science newspaper texts functions in close relationship with the established knowledge. The basic principle of the interaction between the established and the new knowledge in the popular science text is their opposition, which is, in most cases, expressed by means of adverbials of time related to the past and the present, lexical units with the meanings of 'new', 'related to the present', 'first'. There is an opposition between the past and the present tense forms of the verb. In addition, the opposition of the established and the new knowledge is usually expressed explicitly.

\section{REFERENCES}

Баженова, Е. А. (2001). Научный текст в аспекте политекстуальности. Пермь, 269 c.

Данилевская, Н. В. (2005). Динамика формирования знания в научном дискурсе. [In:] Вестник ТГПУ. Серия Гуманитарные науки (Филология). Томск, вып. 3 (47), с. 14 17 .

Данилевская, Н. В. (2009). Оценка как выбор познавательного действия. [In:] Вестник Пермского университета. Серия Российская и зарубежная филология. Пермь, вып. 6, с. 25-30.

Котюрова, М. П. (1989). Смысловая структура русского научного текста и ее экстралингвистические основания (функиионально-стилистический аспект). Автореф. дис. ... д-ра филол. наук : 10.02.01. Свердловск, 32 с.

Хомутова, Т. Н. (2010). Научный текст: теоретические основы интегрального подхода. Автореф. дис. ... д-ра филол. наук : 10.02.19. Москва, 42 с.

Чернявская, В. Е. (2010). Интерпретация научного текста. Москва, 2010. 128 с.

Якубова, В. Ю. (2019а). Взаимодействие участников коммуникации в научнопопулярном тексте. [In:] Немечкий язык - лингводидактическое обеспечение и методика преподавания. Сборник научных статей, посвященный памяти Сергея Александровича Носкова (1943-2018). Е. Е. Иванов (гл. ред.). Могилев, с. 115-119.

Якубова, В. Ю. (2019b). Семантическая структура англоязычной научнопопулярной книги гуманитарной направленности. [In:] Весизі БДПУ. Серия 1: Педагогика, Психология, Филология. № 3 (101), с. 105-109.

Якубова, В. Ю. (2015). Семантическая структура медийного научно-популярного текста и ее языковые маркеры. [In:] Медиатекст и культура. Карпилович Т. П. (гл. ред.). Минск, с. 50-59. 
Anderson, L. W., Krathwohl, D. R. \& Bloom, B. S. (2001). A taxonomy for learning, teaching and assessing: A revision of Bloom's taxonomy of educational objectives [Electronic resource]. URL: https://www.depauw.edu/files/resources/krathwohl.pdf\#page=3\&zoom=auto, -478,708. (date of access : 28.09.2018).

Hyland, K. (2018). Disciplines and discourses: Social interactions in the construction of knowledge [Electronic resource]. URL: https://www.researchgate.net/publication/ 292771083_Disciplines_and_Discourses_Social_Interactions_in_the_Construction_of_Know ledge.pdf. (date of access: 28.09.2018).

Luzón, M. J. (2013). Public Communication of Science in Blogs: Recontextualizing Scientific Discourse for a Diversified Audience. [In:] Written Communication, № 30 (4), pp. 428-457.

Yakubava, V. (2015). Structural semantic, communicative and pragmatic peculiarities of the popular science text. [In:] Даследаванні па германскай і славянскай філалогіi = Acta Germano-Slavica. Магілёў, вып. 6, с. 90-98.

Yakubava, V. (2013). Verbalization of Scientist's Commentary as a Semantic Component in Popular Science Newspaper Articles in the English and Russian Languages. [In:] LANGUAGE - 2013. Language in Various Cultural Contexts. Collection of scientific articles XXIII. Daugavpils, pp. 230-238.

Подано до редакиії 02.10.2019 року

Прийнято до друку 31.10.2019 року 